\title{
EXPERIMENTAL INVESTIGATION OF OPERATING AND DYNAMIC PROPERTIES OF ADSORPTION FILTER PROTOTYPE $^{\dagger}$
}

\author{
UDC 542.745.1
}

\author{
Miomir Raos ${ }^{*}$, Ljiljana Živković, Amelija Đorđević, \\ Jasmina Radosavljević, Emina Mihajlović \\ Faculty of Occupational Safety in Niš, University of Niš, Čarnojevića 10A, 18000 Niš, \\ Serbia
}

\begin{abstract}
The aim of the paper is an examination of flow-thermal, operating and dynamic properties (velocities of gas mixture, flows, pressure drops, temperature, humidity, chemical pollutants tests, and efficiency) and performance of the adsorption filter prototype in the filter-ventilation system. The paper presents the results of the experimental research conducted on the original apparatus in the laboratory for air quality management at the Faculty of Occupational Safety in Niš. The examination of flow-thermal, operating and dynamic parameters of the observed filter prototype was carried out on an experimental ventilation setup with a variable flow rate of gas mixture. Experimental data were registered with appropriate measuring equipment, which helped us obtain a picture of the behavior of the adsorption filter prototype compared to simulated parameters of the gas mixture. By measuring and data acquisition, we reached the assumptions for identifying the observed process, and thus the possibility of modeling and controlling process parameters.
\end{abstract}

Key words: air purification, ventilation, adsorption filter

\section{INTRODUCTION}

Figure 1 shows the schematic of filter-ventilation system elements with a system for data acquisition. The elements of a filter-ventilation system represent the electromechanical system for experimental testing and simulation of flow, thermal, and operating parameters of the gas mixture, and prototypes of filter compartments. Within the frame of the filter-ventilation system, there are elements for air-conditioning and simulation of test pollutants, modules - supports for the emission filter prototypes, as well as measuring and acquisition equipment, components for distribution of the gas mixture and ventilator unit with flow regulation.

Received November $14^{\text {th }}, 2011$, accepted February $27^{\text {th }}, 2012$.

${ }^{\dagger}$ Acknowledgement: This paper has been founded by the Serbian Ministry of Science under the project III-43014.

* Corresponding author. E-mail: miomir.raos@znrfak.znrfak.ni.ac.rs 


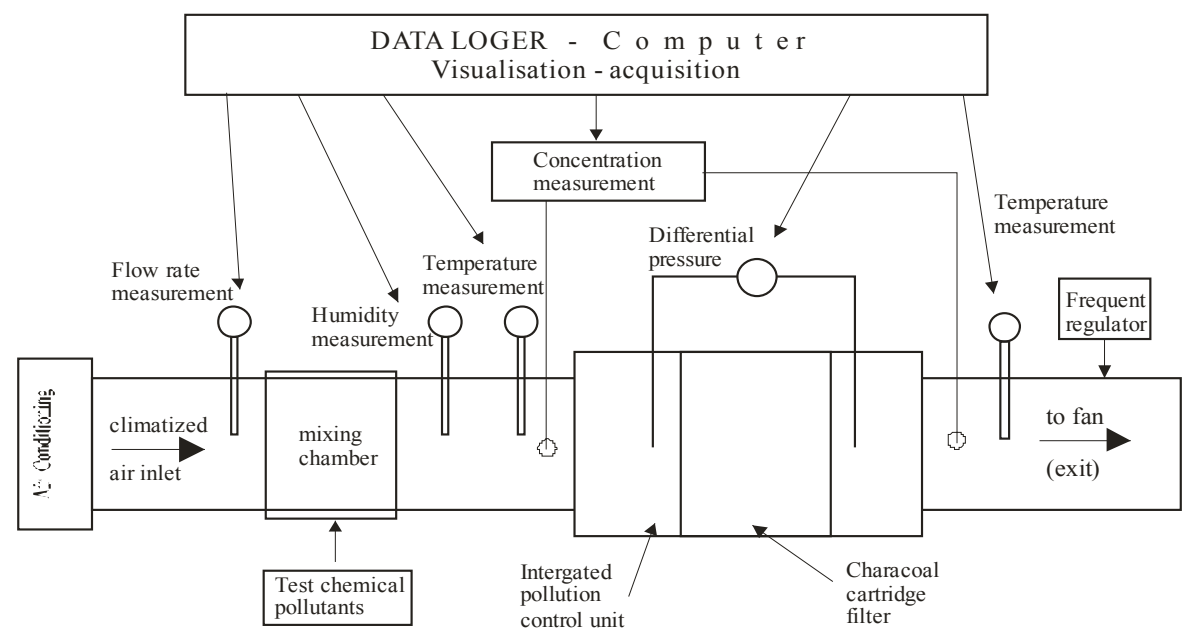

Fig. 1 Schematic of the filter-ventilation system with data acquisition system

\section{Concept of the Cleaner Module for Gaseous Chemical Pollutants}

The cleaner module for chemical pollutants is a compact input-output line segment of the filter-ventilation line, which includes two oppositely directed diffusers and a connecting element of the square cross-section between them. A panel was made of plastic material (PVC) by adequate vacuum processing method, which resulted in proper compactness, strength, and smoothness of the interior walls of modules. This is important because of the module's good mechanical resistance to vibration when the gas mixture flows through the module. Total length of the cleaner module for chemical pollutants is $1270 \mathrm{~mm}$. Connection of diffusers with the body of the module is made by flanges, bolts, and nuts with a suitable sealing element in the flange.

Figure 2 provides an overview of the cleaner module for chemical impurities with measuring and data acquisition equipment.
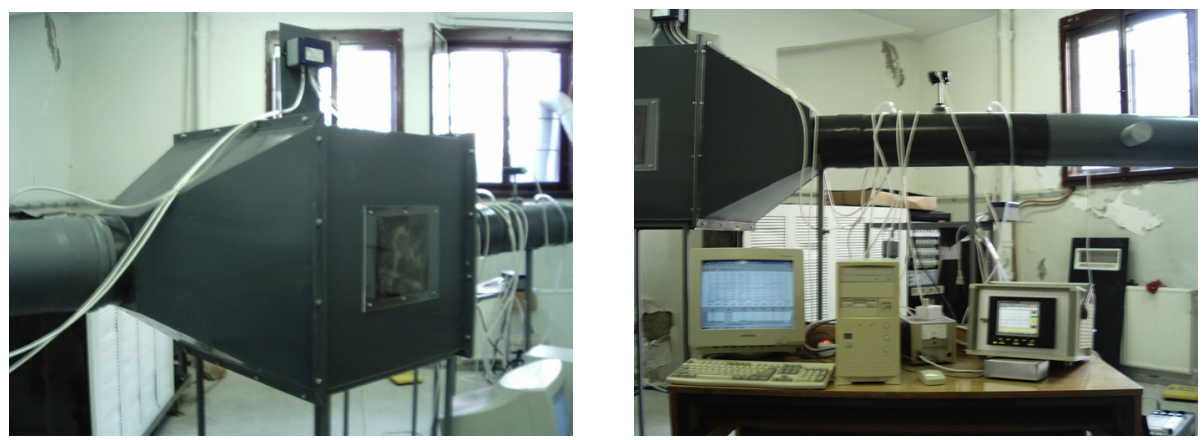

Fig. 2 Cleaner module for chemical pollutants with air ducts (fig. left), on top differential pressure transmitter, (fig. right, behind - air conditioning unit, in front - measuring and data acquisition) 
We stored adsorption filling in the form of cartridges, filled with activated carbon, in the cleaner module for chemical pollutants. The main function of the modules for treatment of chemical pollutants is to provide adequate housing and position of cartridges or activated carbon fillings, and to provide adequate flow characteristics of the gas mixture when it passes through adsorption filling.

\section{Cleaner of Gaseous Chemical Pollutants}

Selection of a cleaner of chemical pollutants is conditioned by the very nature of pollutants, the conditions in which it is used, the desired degree of separation of impurities, capacity, features, ventilation system, etc.

In the experimental part of the paper, we used the adsorption filter prototype with activated carbon as a filling, which was developed in cooperation with local manufacturers of purification systems - Eco Engineering from Bor ${ }^{2}$.

Activated carbon was placed in proper cylindrical cartridge prototypes, with a precisely defined size, adequate resistance to chemical and mechanical effects, and low aerodynamic resistance to the passage of the gas mixture through the cleaner module.

Figure 3 shows a cartridge filled with activated carbon.
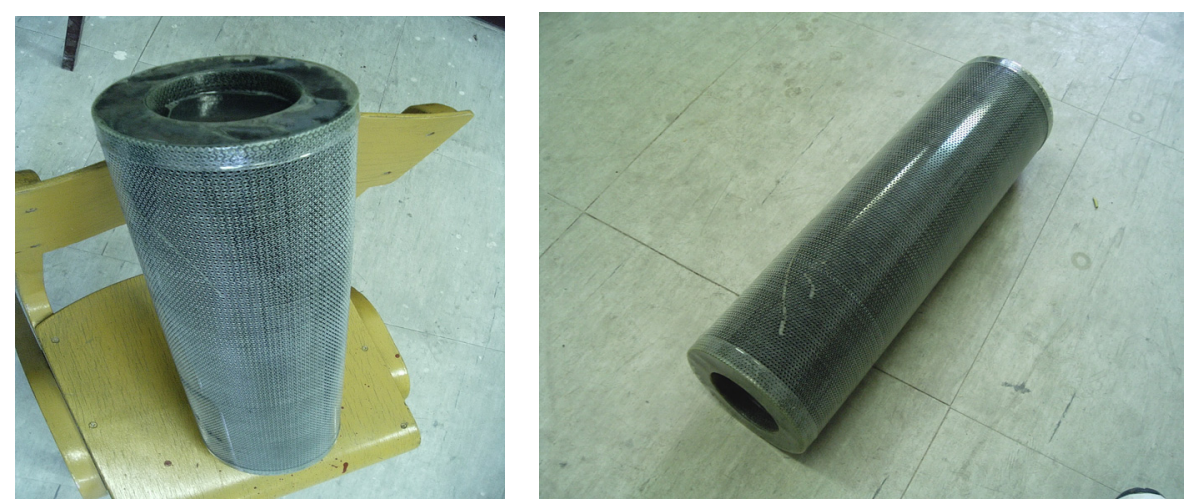

Fig. 3 Cartridge with activated carbon

The cartridge is cylindrical, and its axis corresponds to the flow direction of the gas mixture, which ensures an axial input of the gas mixture into the cartridge area, and then, by a radial flow direction through adsorption filling, its output from the cleaner module for chemical impurities. Radial movement of the gas mixture through the adsorber layer is possible due to existence of a blind panel which the gas mixture strikes when entering the cleaner module and due to perforated inner and outer layer of the cartridge. Size of the perforation is less than the grain size of the adsorber - activated carbon, so as to avoid grains falling through the holes of cartridge layers.

Cartridge housing is made by perforation of acid-resistant plastic film, $1.4 \mathrm{~mm}$ thick (variable number and size of perforations per square centimeter), thus reducing the weight and price of the filters. The cartridges are in a chessboard layout and form a cluster group that is built into the adsorption filter module.

\footnotetext{
${ }^{2}$ Eco Engineering, Dr Milovanovića 4, 19210 Bor, tel. +381 30 435990, e-mail: ekoing@yubc.net
} 
Figure 4 shows an adsorption filter in the form of a cluster group, used in the experimental part of the paper.

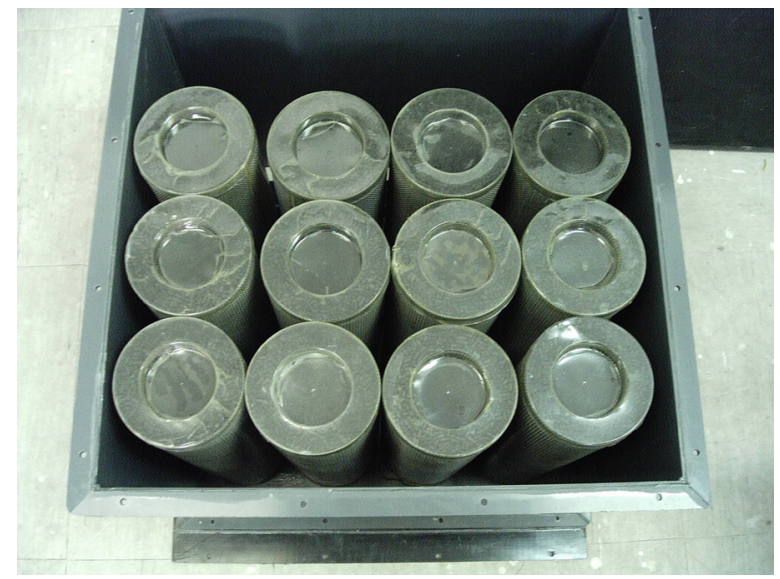

Fig. 4 Adsorption filter in the form of a cluster group

For adsorption filling of the cleaner module for chemical pollutants, we used pellets of activated carbon manufactured by Calgon Carbon Corporation from USA (European Branch - Chemviron Carbon) with different granularity $(3 \mathrm{~mm}, 4 \mathrm{~mm})$, Envirocarb ${ }^{\mathrm{TM}}$ series AP4-60 AP4-60 [4].

This type of activated carbon has a very high density that contributes to a fairly good volume activity, which is important if the activated carbon is used as adsorbent in the form of volume structures. In addition to this positive feature, activated carbon pellets in this series are characterized by good mechanical strength, easy and inexpensive recycling, low ash content, resistance to thermal loads, and low pressure drop of activated carbon in a layer. This results in reduction of fan strain (less power). EnvirocarbTM AP series is currently widely used in the fields of ventilation and air conditioning, treatment of volatile organic compounds (VOC), groundwater remediation, treatment of aerosols during painting and lacquering, solvent reparation (with moderate boiling points, e.g. benzene), treatment of industrial odors, treatment of kitchen fumes, and so on.

\section{Test Gaseous Chemical Pollutants Used IN THE EXPERIMENT}

A simulation of test chemical pollutants is conducted by means of a controlled dosage of gaseous test chemical pollutants. This module contains the source-reservoir of chemical pollutants, proper measuring and regulating apparatus, as well as elements for insertion into the air duct.

For the experimental part of the paper, we used Isobutylene ${ }^{3}$ as a test chemical pollutant, an organic chemical compound with the formula $\mathrm{C}_{4} H_{8}$ [5]. Isobutylene is a hydrocarbon that occurs in nature both from natural and from anthropogenic sources. It is a part of natural gas and crude oil. Its presence is usually associated with the environments such as

\footnotetext{
${ }^{3}$ Isobutylene has been proposed as a standard gas for Thermo Organic Vapor Meter VM 580S II used in experiment.
} 
oil and natural gas source, refineries, gas stations, and reservoirs. In addition, its presence is substantial in urban and suburban environments and comes from fossil fuel combustion. Anthropogenic sources of isobutylene are associated with different technologies to obtain this gas. Isobutylene is obtained commercially by procedures of catalytic or thermal cracking of petroleum fractions, and by various other procedures, such as dehydration tert-butyl alcohol, thermal dehydrogenation of isobutylene, and so on. Concentrations of isobutylene are recorded in urban settings in the range from 1 to 10ppm (according to the Manufacturing Chemists Association, Inc., 1974). Atmospheric conditions significantly degrade isobutylene through photochemical processes.

\section{RESUlTS OF EXPERIMENTAL RESEARCH - OPERATING PROPERTIES OF ADSORPTION FILTER PROTOTYPE}

The group of tests shows concentrations of gaseous test samples in front of and behind the adsorption filter. Concentrations were displayed in terms of velocity and flow of the gas mixture in the ventilation duct. Additionally, we presented a comparative view of concentrations depending on temperature and relative humidity of the gas mixture.

Generally, there is noticeable change in concentration in the secondary air duct at the entrance of the adsorber module, which shows a trend of rapid growth when the gas flow is launched through the test line. Simultaneously, the concentration exiting the adsorber module in the tertiary air duct has a very low value, which indicates intensive extraction of gas impurities in the adsorption filling. As the velocity of gas mixture in the duct increases, there is a decline in input concentration as a result of increasing amount of fresh air intake compared to the same amount of test chemical pollutants (gas substance), up to values close to zero, which indicates a large percentage share of air intake in relation to small input concentrations of the gas. On the other hand, the output concentration retains extremely low values until the velocity of gas mixture at about $0.3 \mathrm{~m} / \mathrm{s}$ in the adsorber module, which indicates a good function of the adsorption filter, which operates in this range with the efficiency percentage of $93-97 \%$.

Increased velocity of the gas mixture in the duct leads to increased output gas concentration up to the velocity of the gas mixture when the output and input concentration values of test isobutylene begin to overlap. This indicates extremely high velocities and flow rates of the gas mixture, when the adsorption filling is not able to adequately separate the gas and there is slight "passing", rather than separation, of the gas mixture. Efficient adsorption process involves specific time of contact that is different from the nature of chemical contaminants, flow conditions, thermodynamic parameters, and adsorption filling properties.

It is necessary to design the adsorption module so that it has moderate flow velocities in order to achieve adequate contact time and, consequently, the maximum separation of gaseous impurities.

Figures 5-8 provide a comparison of concentrations, first in front of and then behind the adsorption filter in function of the thermodynamic parameters and velocity of gas mixture through the test line. We can observe the dependence of adsorption processes on changes in temperature and humidity of gas mixture. As shown in the figures, when the temperature of the gas mixture is increased, there is reduced activity of the adsorber which is manifested through an increase in output concentrations of test gaseous impuri- 
ties. The increase is more prominent if the velocity increases, or the contact time decreases. On the other hand, low humidity affects the increase of input concentrations of test pollutants. Generally, high velocity gas mixture adversely affects the adsorption process because of the reduction of contact time between the gas mixture and the adsorption layer. Experiments reveal that lower moisture content in the air and lower operating temperatures are more favorable to the adsorption process because the adsorption process is prominently exothermic.

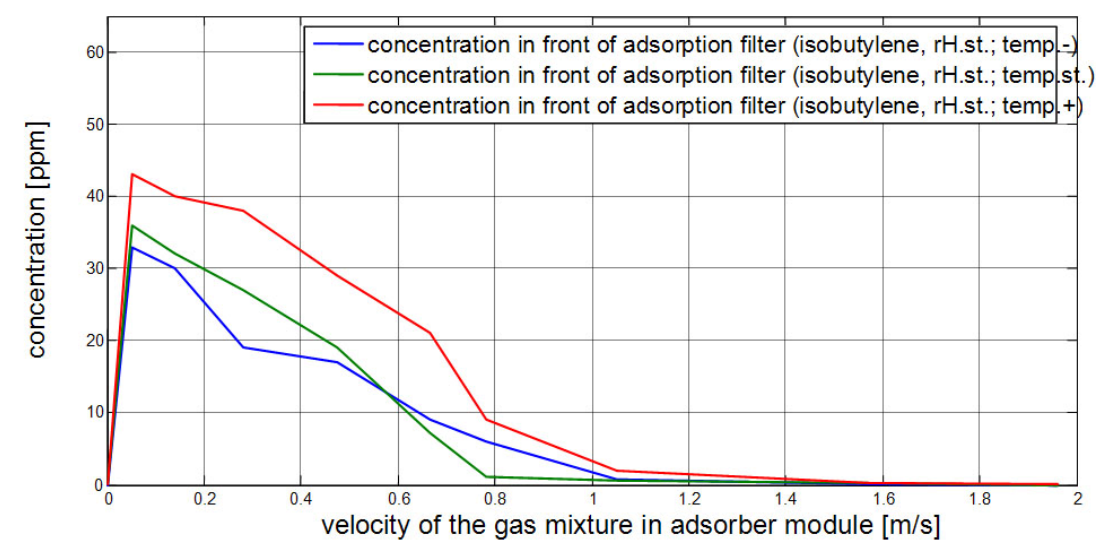

Fig. 5 Change of concentration (adsorption filter entrance) in function of gas mixture velocity (Isobutylene, rH st., temp .-, st., +)

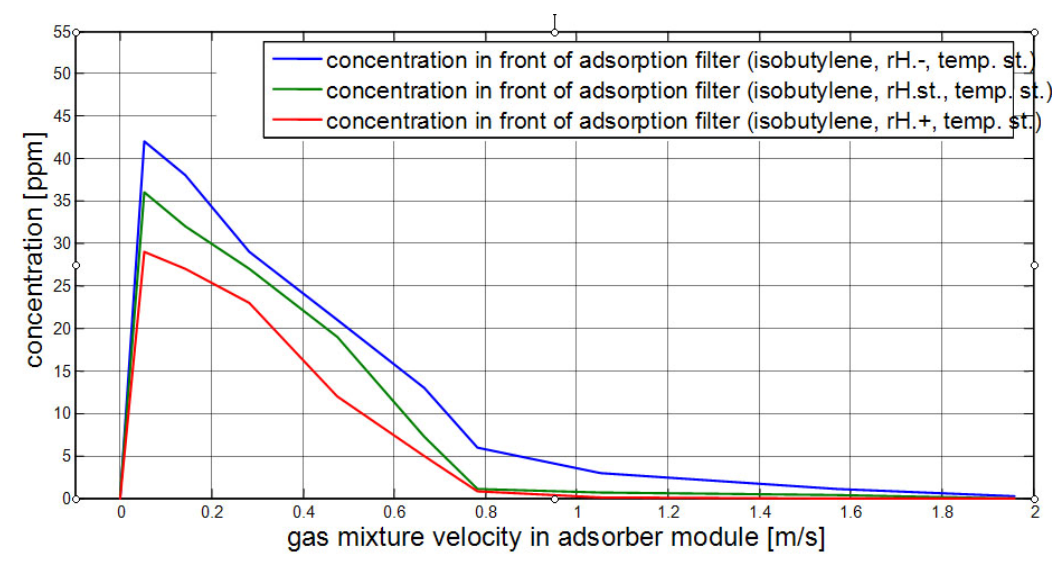

Fig. 6 Change of concentration (adsorption filter entrance) in function of gas mixture velocity (Isobutylene, $\mathrm{rH}-$, st., +; temp. st.) 


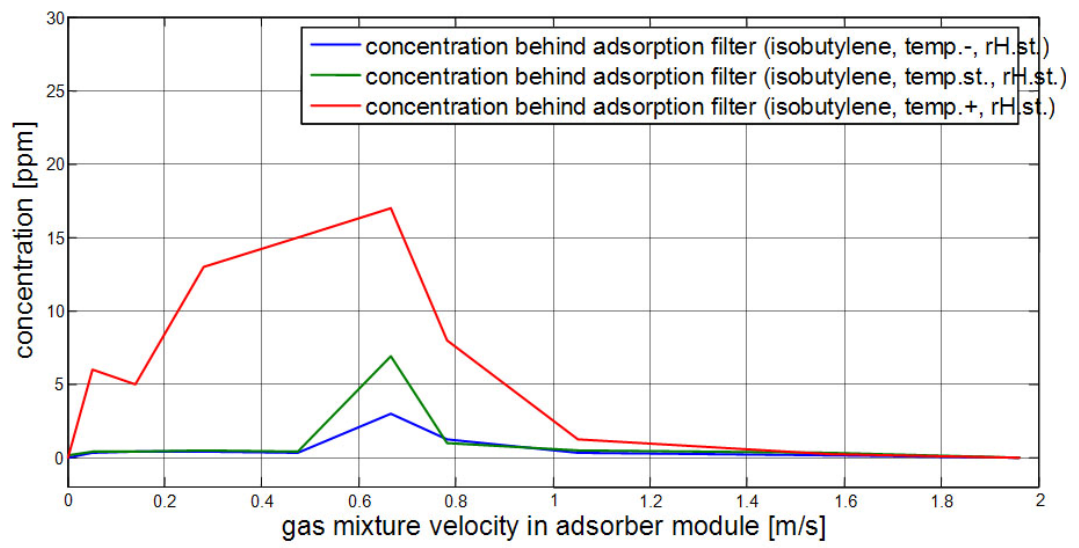

Fig. 7 Change of concentration (adsorption filter exit) in function of gas mixture velocity (Isobutylene, rH st., temp. -, st.,+)

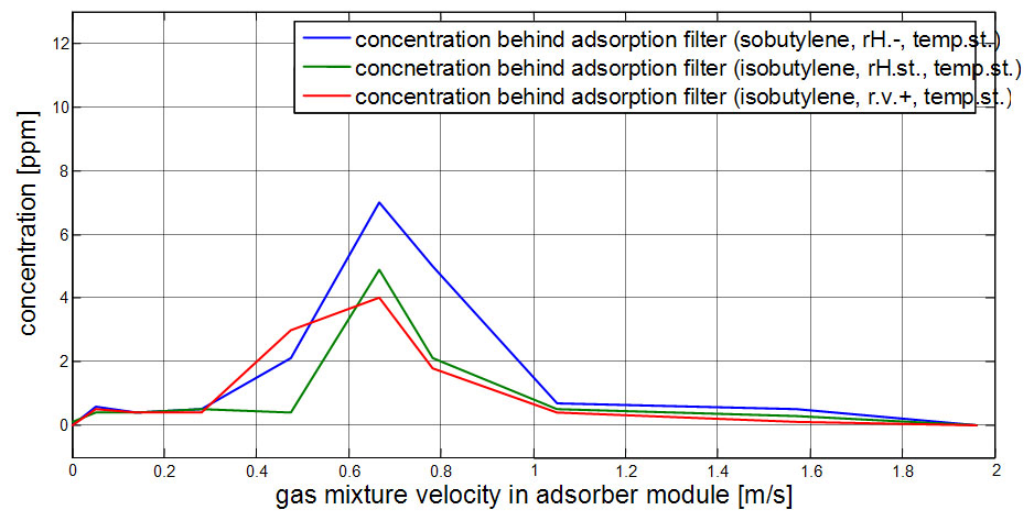

Fig. 8 Change of concentration (adsorption filter exit) in function of gas mixture velocity (Isobutylene, rH -, st., +; temp. st.)

\section{RESUltS OF EXPERIMENTAL RESEARCH - DYNAMIC PROPERTIES OF ADSORPTION FILTER PROTOTYPE}

In this group of dynamic tests, adsorption filter (activated carbon cartridges) was exposed to standard microclimatic conditions. This implies relative humidity values of (50$55 \%)$ and temperature of $\left(22-23^{\circ} \mathrm{C}\right)$, with constant recommended velocity values in the test line and a constant flow of the gas mixture. Recommendations pertain to the contact time of the gas mixture and adsorption charge from 3 to $5 \mathrm{sec}$, allowing a maximum separation of gaseous impurities in the process of adsorption. At the entrance of the primary air duct, the gas mixture is dosed with a constant concentration of the test pollutant, isobutylene. The diagrams show changes in flow and thermodynamic parameters of the gas 
mixture, temperatures, relative humidities, velocities and differential pressures on the adsorption filter, and changes of input and output concentrations of isobutylene in front of and behind the adsorption filter. The process of dynamic testing of the adsorber is terminated when the input concentration reaches the exit of the adsorption filter, i.e. after the filter breakthrough.

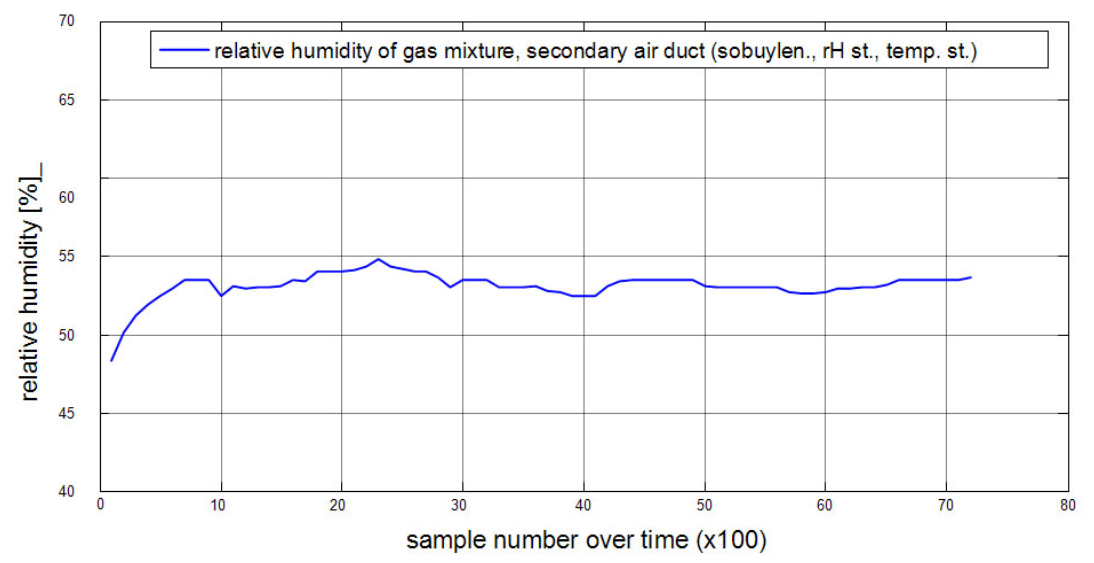

Fig. 9 Change of the relative humidity of air through adsorption filter (Isobutylene, rH st.; temp. st.)

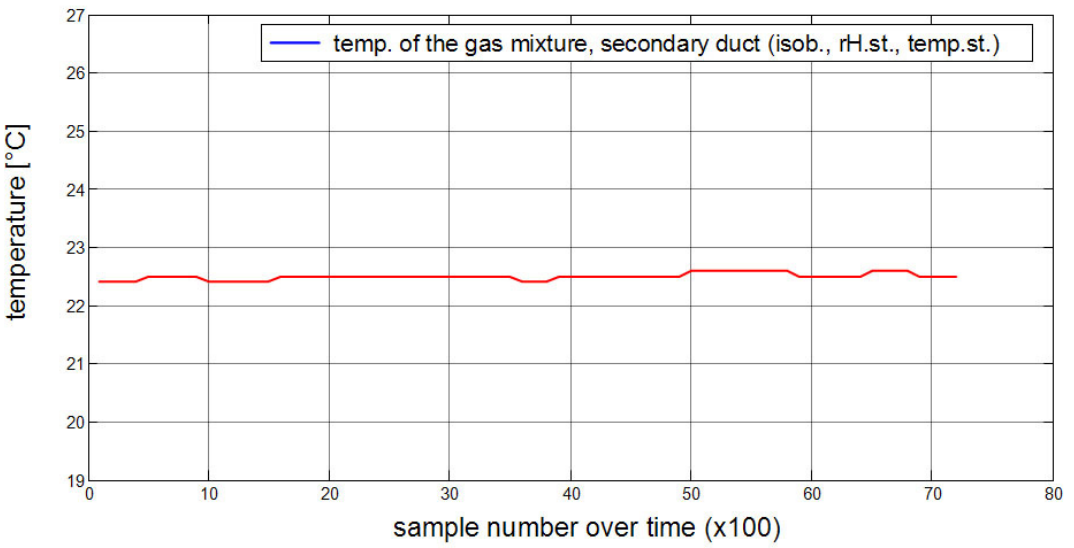

Fig. 10 Change of air temperature of the filter (Isobutylene, rH st.; temp. st.) 


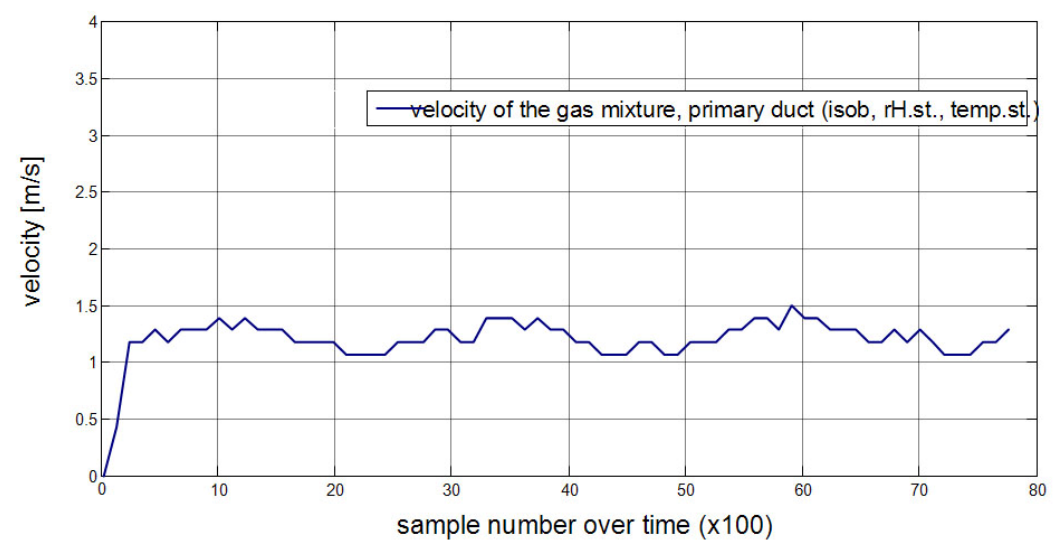

Fig. 11 Change of air velocity through adsorption filter (Isobutylene, rH st.; temp.st.)

Figure 12 shows the change in concentration in front of and behind the adsorption filter. Although the appearance of the output concentration curve changes (up to about $46 \times 100$ samples) is a straight line, in reality it is not straight and changes intensively within a very narrow range of 0.4 to $0.6 \mathrm{ppm}$. However, due to the large scale of the diagram, this change is seen as a straight line. Over the number of $46 \times 100$ samples there is a significant increase in the output concentration value of and it approaches the input value. This means that the adsorption filter is being saturated up to the moment when it no longer collects the test pollutant - Isobutylene, i.e. when the adsorption filter breakthrough actually occurs. From that moment, the adsorption filter is practically unusable and must be replaced.

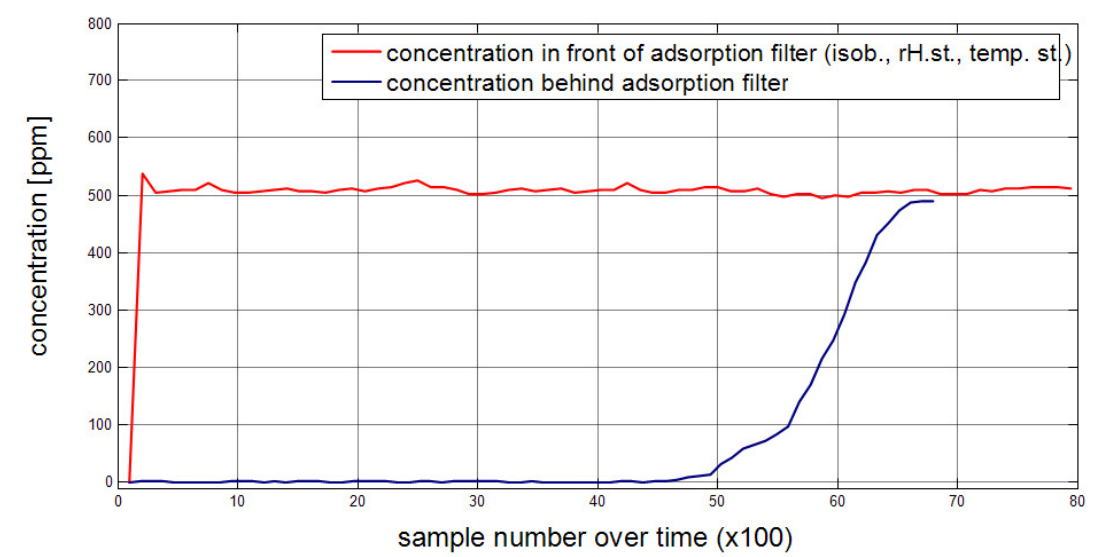

Fig. 12 Change of concentration (adsorption filter entrance and exit in function of sample number (x100, Isobutylene, $\mathrm{rH}$ st.; temp.st.)

Figure 13 shows the change of differential pressure on the adsorption filter. Change of differential pressure is relatively small and, as observed by previous researches, it does 
not significantly affect the functioning of the filter-ventilation system as a whole. As seen from the chart, values of differential pressure range from 290 to $320 \mathrm{mbar}$, so this effect can be neglected in the overall assessment of the filter-ventilation system.

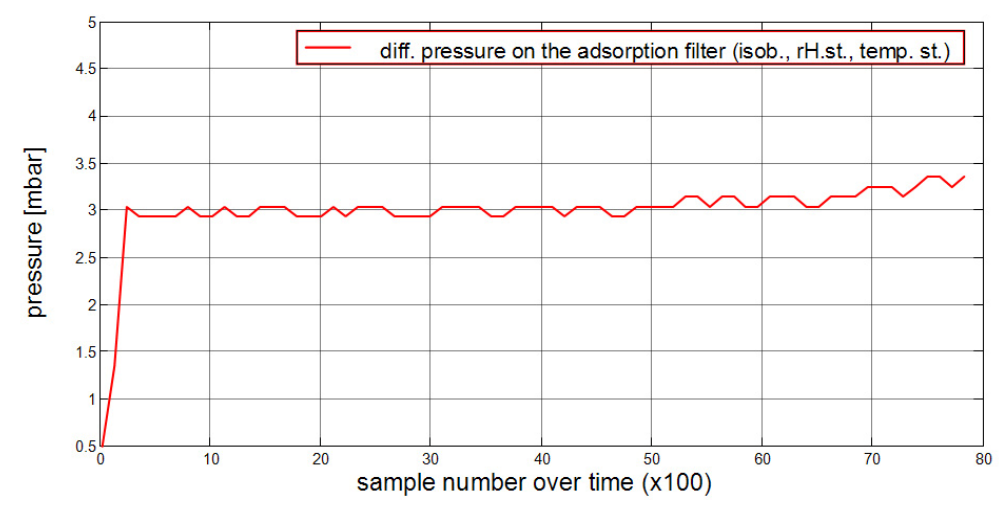

Fig. 13 Change of differential pressure on the adsorption filter in function of sample number (x100, Isobutylene, rH st., temp. st.)

\section{EFFICIENCY OF ADSORPTION FILTER PROTOTYPE}

Adsorption filter efficiency is determined based on the analysis of input and output test pollutant concentrations, measured during dynamic testing to the breakthrough (saturation) point. Initial efficiency of the adsorption filter is very high, about 0.97 , and decreases with time as the adsorption filling is saturated. Figure 14 shows that the curve of efficiency changes of the adsorption filter has a high and constant value at the beginning until about 4500 samples per time when it begins to show a declining trend. The characteristic slope of the curve of efficiency changes is different for each adsorbent and adsorption filter and it results from complex adsorption kinetics and the conditions in which the process of adsorption takes place.

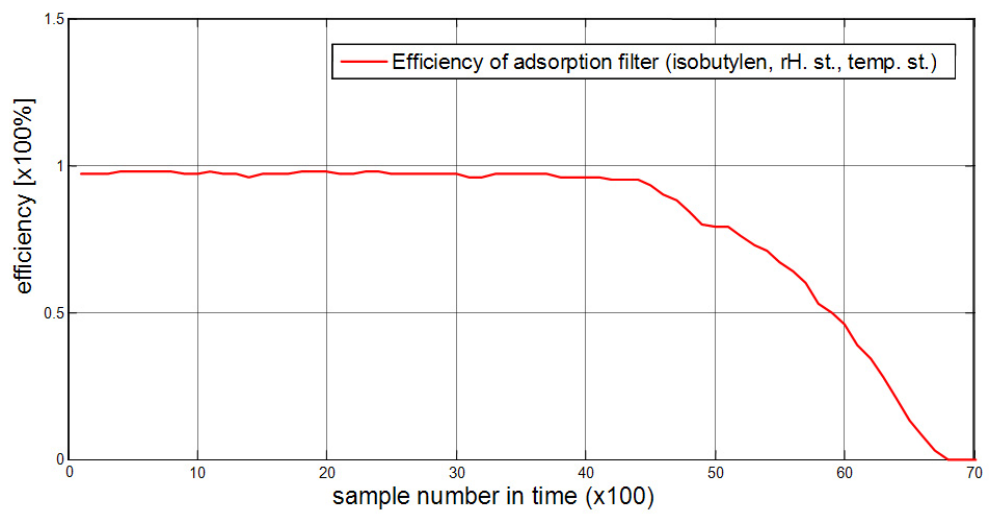

Fig. 14 Change of efficiency of the adsorption filter in function of sample number $(\times 100$, Isobutylene, rH st., temp. st. $)$ 


\section{CONCLUSION}

The paper presents the results of experimental examination of flow-thermal parameters and dynamics properties of the adsorption filter prototype in the filter-ventilation system. Specificity of the adsorption filter prototype is design, geometry and material used for housing of the filter. Cartridge housing is made by perforation of acid-resistant plastic film with variable number and size of perforations per square centimeter, thus reducing the weight and price of the filters. The cartridges are in a chessboard layout and form a cluster group that is built into the adsorption filter module made from plastic material (PVC) by adequate vacuum processing method. All structural features contribute to a good efficiency, lower weight and lower cost of the cartridge and adsorption module. Dynamic characteristics of adsorption filter are very good and characterized by low pressure drop in relation to changes in temperature, humidity and velocity of the gas mixture in the ventilation system. Also, adsorption filter is characterized by good separation of test gaseous pollutants and large capacity allocation.

Experimental data were registered with appropriate measuring equipment, which helped us obtain a picture of the behavior of the adsorption filter prototype compared to simulated parameters of the gas mixture. Therefore, by measuring and data acquisition, we reached the assumptions for identifying the observed process, and thus the possibility of modeling and controlling process parameters as well as structural characteristics of the adsorption filter.

\section{REFERENCES}

1. M. Raos, Lj, Živković, A. Đorđević, B. Todorović, Modelling of the filter-adsorber type air cleaner by using neural network, Facta Universitatis, Series: Physics, Chemistry and Technology, 7 (1), 23-31 (2009).

2. M. Raos, Lj. Živković, A. Đorđević, N. Živković, J. Radosavljević, Concept of the filter-adsorber type integrated air purifier, Facta Universitatis, Series: Physics, Chemistry and Technology, 8 (1), 57-66 (2010).

3. M. Raos, Lj. Živković, N. Živković, B. Todorović, Modeling of air pollution control devices using neural networks, Facta Universitatis, Series: Workig and Living Environmental Protection, 2 (5), 485-492 (2005).

4. M. Raos, Lj. Živković, B. Todorović, N. Živković, A. Đorđević, J. Radosavljević, Modeling of parameters of the air purifying process with a filter-adsorber type purifier by use of neural network, Strojarstvo, 53 (3), 165-170 (2011).

5. Envirocarb ${ }^{\mathrm{TM}}$, Adsorption capacity, Chemviron Carbon, Application \& Service Bulletin, European operations of Calgon Carbon Corporation, Belgium, 2004., Calgon Carbon, Pittsburg, PA, USA, 2004.

6. Isobutylene CAS:115-11-7, Product Identification, Airgas Inc., Randor, PA, USA, 1998.

\section{EKSPERIMENTALNO ISTRAŽIVANJE RADNIH I DINAMIČKIH KARAKTERISTIKA PROTOTIPA ADSORPCIONOG FILTRA}

\section{Miomir Raos, Ljiljana Živković, Amelija Đorđević, Jasmina Radosavljević, Emina Mihajlović}

Cilj rada predstavlja istraživanje strujno-termičkih, radnih i dinamičkih parametara (brzine gasne smeše, protoka, padova pritiska, temperatura, vlažnosti, koncentracija test hemijskih zagađujucih supsatnci, stepena korisnosti) i karakteristika prototipa adsorpcionog filtra u filtroventilacionom sistemu. U radu su izloženi rezultati dela eksperimentalnih istraživanja sprovedenih na originalnoj aparaturi u okviru Laboratorije za upravljanje kvalitetom vazduha na Fakultetu 
zaštite na radu u Nišu. Ispitivanje strujno termičkih, radnih i dinamičkih parametara posmatranog prototipa adsorpcionog filtra vršeno je na eksperimentalnoj aparaturi sa promenjivim protokom gasne smeše. Eksperimentalni podaci registrovani su odgovarajućom merno akvizicionom opremom čime je dobijena slika o ponašanju prototipa adsorpcionog filtra u odnosu na simulirane parametre gasne smeše. Merenjem i akvizicijom ostvaruju se pretpostavke za identifikaciju posmatranog procesa, a time i mogućnost modeliranja i upravljanja parametrima procesa.

Ključne reči: ventilacija, prečišćavanje vazduha, adsorpcioni filter 